\title{
Microbiological study of neonatal septicemia with special reference to metallo-beta-lactamase producing pseudomonas aeruginosa
}

\author{
Dwivedi $\mathbf{V}^{1}$, Murthy $\mathbf{R}^{2}$, Pradhan $\mathbf{S}^{3}$, Agrawal $E^{4}$ \\ ${ }^{1}$ Varun Dwivedi, Phd Research Scholer, Dr. C.V. Raman University, Bilaspur, C.G., ${ }^{2}$ Dr. Ramanesh Murthy \\ Professor and HOD, Department Of Microbiology, CIMS, Bilaspur (C.G.), ${ }^{3}$ Dr. Sagarika Pradhan, Assistant. Professor \\ Department Of Microbiology, CIMS, Bilaspur (C.G.), ${ }^{4}$ Dr. Ekta Agrawal, Assistant Professor, Department Of \\ Microbiology, CIMS, Bilaspur, C.G., India
}

Address for correspondence: Varun Dwivedi, Email: varun.setwin@gmail.com

\begin{abstract}
Introduction: Metallo-beta-lactamase $(\mathrm{M} \beta \mathrm{L})$ producing Pseudomonas aeruginosa has emerged as a potential threat in cases of neonatal septicemia and poses great therapeutic challenge for physicians treating such infections. The emergence, selective multiplication \& dissemination of antibacterial resistance are a serious global problem. Methods: This study was conducted with the objective to know the microbiological profile of neonatal septicemia cases and to examine the incidence of $\mathrm{M} \beta \mathrm{L}$ producing strains among multidrug resistant (MDR) Pseudomonas aeruginosa from the suspected cases of neonatal sepsis between January 2012 - December 2014. A total of 994 cases admitted with the suspicion of neonatal sepsis were investigated. 295 (29.7\%) isolates were obtained from the blood cultures of neonates. The isolates were identified and tested for the susceptibility to various antimicrobial agents. Results: Pseudomonas aeruginosa with 116 (48.3\%) isolation among 240 Gram negative isolates was the predominant pathogen in our study. All the 74 (63.8\%) multidrug resistant $P$. aeruginosa isolates were screened initially for Imipenem resistance, which were further tested for the presence of $\mathrm{M} \beta \mathrm{L}$ by Imipenem-ethylene diamine tetraacetic acid (EDTA) disc method. M $\beta \mathrm{L}$ production was seen in 20 (71.4\%) of the 28 Imipenem-resistant Pseudomonas aeruginosa isolates. Conclusion: It creates a great therapeutic problem as it may spread rapidly to various other species of Gram-negative bacilli. Therefore, to prevent the further spread of M $\beta \mathrm{L}$ producers, it is essential to rapidly detect $\mathrm{M} \beta \mathrm{L}$-positive isolates.
\end{abstract}

Keywords: Metallo-beta-lactamase, Neonatal Sepsis, Pseudomonas Aeruginosa.

\section{Introduction}

The antibiotic resistance among Gram-negative bacteria has been attributed to the efficient methods of transfer of genetic information among bacteria that can confer resistance to one or multiple antibiotics [1].

The increase in resistance of gram negative bacteria is faster than gram positive bacteria $[2,3]$. Still there are some newer antibiotics available, which are active against gram negative bacteria. $[4,5,6]$. The betalactamase resistance is increasing in the members of the family Enterobacteriaceae and non-fermenters like $P$. aeruginosa and Acinetobacter spp. [7]. Neonatal septicemia is responsible for one-fourth to nearly half of the neonatal deaths next to perinatal hypoxia [8]. Infections with $P$. aeruginosa are usually late in onset,

\footnotetext{
Manuscript received: $4^{\text {th }}$ June 2015

Reviewed: $25^{\text {th }}$ June 2015

Author Corrected: $4^{\text {th }}$ July 2015

Accepted for Publication: $12^{\text {th }}$ July 2015
}

nosocomial in origin and epidemic in pattern. $P$. aeruginosa, exhibits intrinsic resistance to various antimicrobial agents including $\beta$-lactam antibiotics.

There has been an increase in carbapenem resistance which is acquired through Metallo-beta-lactamase $(\mathrm{M} \beta \mathrm{L})$ and reported mainly for $P$. aeruginosa and Acinetobacter spp. Therefore, $P$. aeruginosa must be considered as serious pathogen in all neonatal infections, regardless of the age of onset, so that early, appropriate and often life-saving antibiotic therapy may be instituted [9].

The present study was designed to know the incidence of different micro-organism causing neonatal septicemia, their antibiotic susceptibility pattern and to detect the presence of $\mathrm{M} \beta \mathrm{L}$ among the imipenemresistant isolates of $P$. aeruginosa. 


\section{Material \& Methods}

The present study was undertaken during January 2012 to December 2014 at Chhattisgarh Institute of Medical Sciences, Bilaspur, Chhattisgarh. A total of 994 blood cultures were received in the Microbiology Department, from clinically suspected cases of neonatal septicemia [10]. Blood was collected with full aseptic measures according to standard guideline [11]. The blood culture bottles (HiSafe ${ }^{\mathrm{TM}}$ Blood Culturing System, Paediatric use - Hi-media, Mumbai) were incubated at $37^{\circ} \mathrm{C}$ for 7 days. Subcultures were done first at 24 hours, then at 72 hours and on the fifth day onto the blood agar and Mac Conkey's agar plates. Organisms isolated were identified by the standard methods of identification [12].

\section{Results}

Out of 994 blood cultures from neonates, 295 (29.7\%) showed bacterial growth. The growth was detected in the 230 $(77.9 \%)$ cultures in the first 10 days of life. Gram-negative septicemia was encountered in $240(81.3 \%)$ cases while Gram-positive cocci were isolated in remaining 55 (18.7\%) cases (Table-1). P. aeruginosa isolated in $116(48.3 \%)$ was the predominant pathogen among Gram-negative isolates, whereas coagulase negative Staphylococci (CoNS) were the most common Gram-positive pathogens.

Table 1: Antimicrobial resistance pattern of organisms isolated from neonatal septicemia cases

\begin{tabular}{|c|c|c|c|c|c|c|c|c|c|}
\hline \multirow{2}{*}{ Drugs } & $\begin{array}{c}\text { Pseudomonas } \\
\text { aeruginosas }\end{array}$ & $\begin{array}{c}\text { Acinetoba } \\
\text { cter spp. }\end{array}$ & $\begin{array}{c}\text { Enterobac } \\
\text { ter spp. }\end{array}$ & $\begin{array}{l}\text { Escheri } \\
\text { chia coli }\end{array}$ & $\begin{array}{l}\text { Klebsiel } \\
\text { la spp. }\end{array}$ & $\begin{array}{l}\text { Citroba } \\
\text { cter spp. }\end{array}$ & $\begin{array}{l}\text { Co } \\
\text { NS }\end{array}$ & $\begin{array}{c}\text { S. } \\
\text { aureus }\end{array}$ & $\begin{array}{c}\text { Enteroc } \\
\text { occi }\end{array}$ \\
\hline & $(n=116)$ & $(\mathbf{n}=30)$ & $(\mathrm{n}=38)$ & $(\mathbf{n}=27)$ & $(n=15)$ & $(n=14)$ & $\begin{array}{l}(\mathbf{n}= \\
32)\end{array}$ & $\begin{array}{l}(n= \\
18)\end{array}$ & $(\mathbf{n}=05)$ \\
\hline Amikacin & 91.2 & 82.0 & 63.8 & 24.3 & 64.5 & 68.8 & - & - & - \\
\hline Gentamicin & 92.3 & 77.1 & 88.0 & 90.0 & 80.7 & 93.7 & 25.6 & 51.4 & 68.5 \\
\hline Cefotaxime & - & 46.0 & 77.6 & 35.8 & 80.7 & 62.5 & - & - & - \\
\hline Cefazolin & - & - & - & - & - & - & 30.2 & 45.7 & 88.5 \\
\hline Cefuroxime & - & - & - & - & - & - & 26.2 & 40.0 & 62.8 \\
\hline Ceftizoxime & 33.6 & 42.0 & 46.6 & 7.2 & 38.8 & 28.2 & - & - & - \\
\hline Ceftriaxone & - & 65.6 & 88.0 & 42.9 & 94.4 & 62.5 & - & - & - \\
\hline Cetazidime & 59 & - & - & - & - & - & - & - & - \\
\hline Clindamycin & - & - & - & - & - & - & 6.9 & 45.7 & 34.2 \\
\hline Ciprofloxacin & 76.2 & 55.8 & 62.2 & 57.2 & 64.6 & 65.7 & - & - & - \\
\hline $\begin{array}{l}\text { Chlorampheni } \\
\text { col }\end{array}$ & - & 82.0 & 88.0 & 78.6 & 71.0 & 93.7 & 48.8 & 34.2 & 60.0 \\
\hline Erythromycin & - & - & - & - & - & - & 39.5 & 51.4 & 42.8 \\
\hline Piperacillin & 88.8 & - & - & - & - & - & - & - & - \\
\hline Penicillin & - & - & - & - & - & - & 76.7 & 85.7 & 82.8 \\
\hline
\end{tabular}

P. aeruginosa was mostly resistant to Gentamicin (92.3\%), Amikacin (91.21\%), and Piperacillin (88.8\%). In this study, out of $116 P$. aeruginosa isolates 74 (63.6\%) were found to be MDR. Of these, $46(62.1 \%)$ were imipenem-sensitive and $28(37.9 \%)$ were imipenem resistant. Out of 28 imipenem resistant $P$. aeruginosa, M $\beta \mathrm{L}$ production was observed in the $20(71.4 \%)$ (Table-2).

\begin{abstract}
performed by the Kirby Bauer disc diffusion method on Muller Hinton Agar (Hi-media, Mumbai) for antibiotics according to CLSI (Control Laboratory Standard Institute) [13]. All the multi-drug-resistant (MDR) isolates of $P$. aeruginosa were then tested for the sensitivity to imipenem $(10 \mu \mathrm{g}$, Hi Media) and the imipenem-resistant isolates were screened for the method [14]. An increase in zone diameter of $>4$ mm around the IPM-EDTA disk compared to that of the IPM disk alone was considered positive for an MBL. [15].

Antibiotic sensitivity tests of the isolates were
\end{abstract}

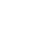

政
(n) 
Table 2: Frequency of M $\mathrm{ML}$ production, Imipenem resistance among MDR $\boldsymbol{P}$. aeruginosa isolates.

\begin{tabular}{|l|c|c|}
\hline & $\begin{array}{c}\text { MDR } \\
\text { Pseudomonas aeruginosa } \\
(\mathrm{n}=74)\end{array}$ & \\
\hline Imipenem resistant & $28(37.9 \%)$ & $\begin{array}{l}20(71.4 \%) \mathrm{M} \beta \mathrm{L}+\mathrm{ve} \\
08(28.6 \%) \mathrm{M} \beta \mathrm{L}-\mathrm{ve}\end{array}$ \\
\hline Imipenem sensitive & $46(62.1 \%)$ & - \\
\hline
\end{tabular}

\section{Discussion}

Blood culture is the most important investigation to confirm the diagnosis of neonatal septicemia. However, positivity of blood culture varies considerably from centre to centre and by the time suspected cases from rural health practitioners, primary or community health centres get referred to tertiary care set-up, the isolation rates are considerably low, often to the dismay of clinicians. It occurs most commonly due to indiscriminate, inappropriate and irrational use of antibiotics and poor compliance, obscuring the efficacy of standard microbiological work-up. In the present study, the incidence of neonatal septicemia confirmed was $29.7 \%$. This is comparable to $30-75 \%$ positivity reported in earlier studies $[16,17]$.

In our study, most of the cases of neonatal septicemia occurred in the first 10 days of life $(77.9 \%)$, a fact that has been reported previously. It probably relates to immaturity of the immune system. This warrants the need for close monitoring of the newborns. With the advent of newer and automated blood culture systems, isolation rates of blood cultures have definitely gone up, but misreporting of contaminants picked-up at the time of collection should be kept in mind and a co-relation with clinical condition should always be ascertained.

A rising incidence of Gram-negative bacteremia has been reported in recent years in neonates [16, 17]. The present study documents the isolation of $240(81.3 \%)$ gram-negative bacilli with $P$. aeruginosa in $116(48.3 \%)$ as the predominant pathogen. $P$. aeruginosa has also been reported to be the most common etiological agent of neonatal septicemia by other researchers $[18,19]$.

Almost all Gram-negative organisms showed resistance to Chloramphenicol (70-95\%) and Gentamicin (5095\%). Reduced chloramphenicol sensitivity (20-44\%) and Gentamicin sensitivity (23-30\%) have been documented by other workers [20, 21, 22]. The overall resistance rate of $P$. aeruginosa to all antimicrobial agents in our study was also significant and accounted for $63.6 \%$ MDR isolates which correlates with the study by Moniri and colleagues (73.9\%) [23]. Multi-drug resistance caused by a variety of resistance mechanisms leads to few therapeutic options. Carbapenems are often used as antibiotics of last resort against this organism. Our study showed $38 \%$ imipenem resistance which is in concordance with Sarkar et al (36.36\%) [24].

With increase in the use of Carbapenems in hospital settings, the problem of $\mathrm{M} \beta \mathrm{L}$ production is also increasing. In our study, 20 (71.4\%) of imipenemresistant isolates were found to be $\mathrm{M} \beta \mathrm{L}$ producers. This is an emerging threat and a matter of concern for the treating physicians. The remaining imipenem resistant isolates may have other mechanisms of resistance such as reduced levels of drug accumulation or increased expression of pump efflux.

In conclusion, incidence of neonatal septicaemia caused by gram negative organism $(81.3 \%)$ was more than that of gram positive organism (28.7\%). Among gram negative organisms $P$. aeruginosa was the most common pathogen isolated $(48.3 \%)$. The MDR strains can cause considerable morbidity and mortality. The study also highlights the emergence of $\mathrm{M} \beta \mathrm{L}$ producing by $P$. aeruginosa in imipenam resistance isolates $(71.4 \%)$.

The increasing occurrence of $\mathrm{M} \beta \mathrm{L}$ producing $P$. aeruginosa isolates is a reality in this tribal- dominated region of Chhattisgarh State, where such studies are almost non- existent and appropriate antibiotic usage is seldom followed [25].

\section{Conclusion}

It creates a great therapeutic problem as it may spread rapidly to various other species of Gram-negative bacilli. Therefore, to prevent the further spread of $\mathrm{M} \beta \mathrm{L}$ producers, it is essential to rapidly detect M $\beta \mathrm{L}$-positive isolates

\section{Funding: Nil \\ Conflict of interest: Nil \\ Permission from IRB: Yes}




\section{References}

1. Poole K. Overcoming multidrug resistance in gram negative bacteria. Curr Opin Investig Drugs. 2003 Feb;4(2):128-39.

2. Cornaglia G. Fighting infections due to multidrugresistant Gram positive pathogen. Clin Microbiol Infect. 2009 Mar; 15(3): 209-11.doi:10.1111/j.14690691.2009.02737.x

3. Tan TT. "Future" threat of gram-negative resistance in Singapore. Ann Acad Med Singapore 2008 Oct;37(10): 884-90.

4. Baiden F, Owusu-Agyei S, Webstar J, Chandramohan D. The need for new antibiotics. Lancet. 2010 Feb; 375(9715): $\quad$ 637-38.doi;10.1016/S01406736(10)60265-6.

5.Vento S, Cainelli F. The need for new antibiotics. Lancet. 2010 Feb; 375(9715): 637. doi:10.1016/S01406736(10)60264-4.

6. Wise R, Piddock L. The need for new antibiotics. Lancet. 2010 Feb; 375(9715): 638.doi:10.1016/S01406736(10)60266-8.

7. Neuhauser MM, Weinstein RA, Rydman R, Danziger LH, Karam G, Quinn JP. Antibiotic Resistance among gram negative bacilli in US intensive care units implications for fluoroquinolone use. JAMA. 2003 Feb; 289(7): 885-88.

8. Sharma A, Kutty CVK, Sabharwal U, Rathee S, Mohan H. Evaluation of sepsis screen for diagnosis of neonatal septicemia. Indian J Pediatr. 1993 JulAug;60(4): 559-63.

9. Barton LL, Lustiq RH, Fong CT, Walentic CA. Neonatal septicemia due to Pseudomonas aeruginosa. Am Fam Physician. 1986 Mar;33(3): 147-51.

10. Goldstein B, Giroir B, Randolph A. International pediatric sepsis consensus conference:Definitions for sepsis and organ dysfunction in pediatrics. Pediatr Crit Care Med. 2005 Jan; 6(1):2-8.

11. B.A. forbes, D.F. Sahm, A.S. weissfeld. Diagnostic Microbiology, Bailey \& Scott's. 2007;12:778-97.
12. Collee JG, Duguid JP, Fraser AG, Marmion BP, Simmons A. Laboratory strategy in diagnosis of infective syndromes. In: Collee JG, Fraser AG, Marmion BP, Simmons AC, editors. Mackie and McCartney Practical Medical Microbiology. $14^{\text {th }}$ Ed. Singapore: Churchill Livingstone; 1996.p.53-94.

13. Bauer AW, Kirby WM, Sherris JC, Turck M. Antibiotic susceptibility testing by a standardized single disc method. Tech Bull Regist Med Technol.1966 Mar;36(3):49-52.

14. Yong D, Lee K, Yum JH, Shin HB, Rossolini GM, Chong $Y$. Imipenem-EDTA disk method for differentiation of metallo- $\beta$-lactamases producing clinical isolates of Pseudomonas spp. And Acinetobacter spp. J Clin Microbiol. 2002 Oct; 40(10): 3798-801.

15. Clare Franklin, Lisa Liolios, and Anton Y. Peleg. Phenotypic Detection of Carbapenem-Susceptible Metallo- $\beta$ - Lactamase-Producing Gram-Negative Bacilli in the Clinical Laboratory. J Clin Microbiol. 2006 Sep; 44(9): 3139-3144.

16. De A, Saraswathi K, Gogate A, Fernandes AR. Bacteremia in hospitalized children-A one year prospective study. Indian J Med Microbiol. 1995;13: 72-5.

17. Sharma M, Goel N, Chaudhary U, Aggarwal R, Arora DR. Bacteremia in children. Indian $\mathrm{J}$ Pediatr. 2002 Dec;69(12): 1029-32.

18. Kulkarni A, Vigneswaran R. Acquired neonatal sepsis: Are surveillance cultures helpful? Asian J Pediatr Pract. 2000;4: 11-3.

19. Bhattacharjee A, Sen MR. Prakash P, Gaur A, Anupurba S. Increased prevalence of extended spectrum beta lactamase producers in neonatal septicemic cases at a tertiary referral hospital. Indian J Med Microbiol. 2008 Oct-Dec; 26(4): 356-60.

20. Moniri R, Mosayebi Z, Movahedian AH, Mousavi GA. Emergence of multidrug resistant Pseudomonas aeruginosa isolates in neonatal septicemia. J Infect Dis Antimicrob Agents. 2005; 22: 39-44.

21. Kuciikates E, Kocazeybek B. High resistance rate against 15 different antibiotics in aerobic Gramnegative bacterial isolates of cardiology intensive care 
unit patients. Indian J Med Microbiol. 2002; 20: 20810.

22. Okesola AO, Oni AA. Antimicrobial resistance among common bacterial pathogens in South-west Nigeria. American Eurasian J Agri Env Sci. 2009; 5: 327-30.

23. De A, Deodhar LP. Sensitivity of common bacterial isolates to netilmycin: A potent aminoglycoside. Indian Practitioner. 1992; 45: 599.
24. Sarkar B, Biswas D, Prasad R. A. clinic microbiological study on the importance of Pseudomonas in nosocomially infected ICU patients with special reference to metallo- $\beta$-lactamase production. Indian J Pathol Microbiol. 2006;49: 44-6.

25. Murthy M, Patel S, Patel KK, Murthy R. Emergence of Carbapenem resistance among isolates of Pseudomonas aeruginosa in diabetes patients. J. Microb. World.2010; 12 (1):87-91.

\section{How to cite this article?}

Dwivedi V, Murthy R, Pradhan S, Agrawal E. Microbiological study of neonatal septicemia with special reference to metallo-beta-lactamase producing pseudomonas aeruginosa. Int $J$ Med Res Rev 2015;3(6):618-622. doi: 10.17511/ijmrr.2015.i6.120. 